\title{
A diabeteses polyneuropathia okozta epidemiológiai és egészségbiztosítási betegségteher elemzése egészségbiztosítási adatok alapján
}

\author{
Csákvári Tímea ${ }^{1,2}$ - Elmer Diána ${ }^{2,3}$ - Németh Noémi ${ }^{2,3}$ \\ Kívés Zsuzsanna ${ }^{2,3}$. Wittmann István dr. ${ }^{4}$ \\ Janszky József $\mathrm{dr}^{5}{ }^{5}$. Boncz Imre dr. ${ }^{2,3}$ \\ ${ }^{1}$ Pécsi Tudományegyetem, Egészségtudományi Kar, Egészségbiztosítási Intézet, Zalaegerszeg \\ ${ }^{2}$ Pécsi Tudományegyetem, Egészségtudományi Kar, \\ Real World \& Big Data Egészség-gazdaságtani Kutatóközpont, Pécs \\ ${ }^{3}$ Pécsi Tudományegyetem, Egészségtudományi Kar, Egészségbiztosítási Intézet, Pécs \\ ${ }^{4}$ Pécsi Tudományegyetem, Általános Orvostudományi Kar, Klinikai Központ, \\ II. Belgyógyászati Klinika és Nephrologiai, Diabetológiai Centrum, Pécs \\ ${ }^{5}$ Pécsi Tudományegyetem, Általános Orvostudományi Kar, Klinikai Központ, Neurológiai Klinika, Pécs

\begin{abstract}
Bevezetés: Az idegrendszeri károsodás az egyik leggyakrabban kialakuló komplikáció a cukorbetegek körében, mely az egyénnek és a finanszírozónak is jelentős terhet jelent.

Célkitüzés: Elemzésünk célja volt a diabeteses polyneuropathia okozta epidemiológiai és egészségbiztosítási betegségteher elemzése.

Adatok és módszerek: Az adatok a Nemzeti Egészségbiztosítási Alapkezelő (NEAK) finanszírozási adatbázisából származnak, és a 2018. évet fedik le. Meghatároztuk az éves betegszámokat és a 100000 lakosra jutó igénybevételi prevalenciát, továbbá az éves egészségbiztosítási kiadásokat korcsoportos és nemenkénti bontásban és ellátási típusonként. A vizsgált kórképet a Betegségek Nemzetközi Osztályozása (10. revízió) szerinti G6320-as kóddal azonosítottuk.

Eredmények: A diabeteses polyneuropathia kezelésére a NEAK 6,63 milliárd Ft (24,52 millió USD; 20,78 millió EUR) egészségbiztosítási kiadást fordított 2018-ban. E költségek legnagyobb hányadát a gyógyszerek ártámogatása adta $(78,29 \%)$. A teljes népességre számolt, 100000 före vetített prevalencia 862/100 000 fó volt a férfiak, 981/100 000 fó a nók esetében, együtt 924/100 000 fó a járóbeteg-szakellátásban. A 65-74 évesek jelentek meg a legnagyobb számban az egyes ellátási szinteken. A nemek eloszlása között a legtöbb vizsgált korcsoport tekintetében számottevő különbség nem tapasztalható, 65 év felett azonban már jóval magasabb a nők aránya.

Következtetés: A betegség előfordulási gyakorisága a nők esetében 15,6\%-kal magasabb. Idősebb korban jelentősen magasabb betegszámot figyeltünk meg. A neuropathiás szövődmények elkerülése érdekében a terápiás kezelésen túl a megelőzésre is sokkal nagyobb figyelmet javasolunk fordítani.

Orv Hetil. 2021; 162(Suppl 1): 38-45.
\end{abstract}

Kulcsszavak: diabetes mellitus, neuropathia, polyneuropathia, betegségteher, epidemiológia

\section{Assessing the epidemiological disease burden and health insurance treatment cost of diabetic polyneuropathy based on health insurance claims data}

Introduction: Neurological complications are the most common type of complications among type 2 diabetes mellitus patients, which put a heavy burden on both individuals and health insurance organizations.

Objective: The aim of our study was to determine the epidemiological and health insurance disease burden of noninsulin-dependent diabetes with neurological complications.

Data and methods: Data were derived from the financial database of the National Health Insurance Fund Administration (NHIFA) of Hungary for the year 2018. Data analysed included annual patient numbers and prevalence of care utilisation per 100000 population according to age groups and sex. Patients were identified with the following code of the International Classification of Diseases, 10th revision: G6320. 
Results: In 2018, NHIFA spent 6.63 billion HUF (24.52 million USD; 20.78 million EUR) on treating diabetic polyneuropathy. Reimbursement of pharmaceuticals was the main cost driver $(78.29 \%$ of total expenditure). Based on patient numbers in outpatient care, prevalence in 100000 population was 862 men, 981 women, together 924 people based on outpatient-care utilization. Most patients were aged between 65-74 years in all forms of care. Regarding sex, no significant differences were found among most age groups, however, the ratio of women tends to be higher above 65 years of age.

Conclusion: Prevalence was found to be by $15.6 \%$ higher among women. Significantly higher patient numbers were found in old age. Besides therapeutic interventions, prevention should gain considerably more attention to avoid polyneuropathic complications.

Keywords: diabetes mellitus, diabetic neuropathy, diabetic polyneuropathy, health expenditures, epidemiology

Csákvári T, Elmer D, Németh N, Kívés Zs, Wittmann I, Janszky J, Boncz I. [Assessing the epidemiological disease burden and health insurance treatment cost of diabetic polyneuropathy based on health insurance claims data]. Orv Hetil. 2021; 162(Suppl 1): 38-45.

(Beérkezett: 2021. január 3.; elfogadva: 2021. január 22.)

\begin{abstract}
Rövidítések
BNO = Betegségek Nemzetközi Osztályozása; CT = (comput ed tomography) komputertomográfia; DALY $=($ disability-adjusted life years) egészségkárosodással korrigált életévek; DPN = diabeteses polyneuropathia; EFOP = Emberi Erőforrás Fejlesztési Operatív Program; GBD = (Global Burden of Disease Study) globális betegségteher-tanulmány; MRI = (magnetic resonance imaging) mágnesesrezonancia-képalkotás; NEAK = Nemzeti Egészségbiztosítási Alapkezelő; PET = pozitronemissziós tomográfia; WHO $=$ (World Health Organization $)$ Egészségügyi Világszervezet
\end{abstract}

Napjainkban a fejlett országok legfőbb egészségügyi kihívását a nem fertőző krónikus megbetegedések egyre növekvő száma okozza. A fóként idősebb korban előforduló, gyakran halmozódó betegségek az egyén és az ellátórendszer számára is komoly kihívást jelentenek. A diabetesben szenvedők száma megnégyszereződött 1980 óta, ez 2014-ben már mintegy 422 millió fö́t jelentett világszerte. Az Egészségügyi Világszervezet (WHO) 10,4\%-ra becsüli a cukorbetegség prevalenciáját a magas jövedelmű országokban, mely 2045-re becslés szerint akár 11,9\%-ra növekedhet [1].

A 2-es típusú diabetes mellitus incidenciája csökkenó trendet mutatott Magyarországon az elmúlt évtizedekben [2] - 2001-ben 76645 új megbetegedést regisztráltak, e mutató 37,9\%-kal lett kevesebb 2016-ra. Prevalenciája azonban 321090 fövel növekedett ugyanebben a periódusban, ezzel a magyar lakosság 9,30\%-a volt érintett a betegségben 2016-ban [3].

Különösen nehéz mind társadalmi, mind finanszírozói szempontból a nem megfelelően kezelt diabetes szövődményeinek terápiája, melyek kialakulásuk esetén további életminőség-romlást és többletköltséget generálnak. Sok esetben évekig, évtizedekig is ronthatják a betegek egészségi állapotát, és a betegség hossza bizonyítottan hat a különböző szövődmények kialakulási esélyeire is (például perifériás keringési, szem-, veseszövődmények).
Az idegrendszeri károsodás mint microvascularis szövődmény a leggyakrabban kialakuló komplikáció a cukorbetegek körében. A neuropathia diabetica során egy vagy több, autonóm vagy perifériás ideg károsodik, ami változatos formában jelenhet meg és okozhat tüneteket a betegnek - a leggyakrabban azonban az alsó végtagokat érinti. Ez az életminőséget rontó és jelentős többletköltséget okozó szövődmény az alapbetegséggel rendelkezők akár harmadát érintheti valamilyen formában nemzetközi szakirodalmi közlemények a fájdalommal járó neuropathia előfordulási gyakoriságát 5,8\% és $34 \%$ közöttire becsülik az európai diabeteses populáción belül [4].

Hazánkban a diabeteses populáció csaknem harmadánál valószínűsítik neuropathiás szövődmények, köztük a polyneuropathia jelenlétét [5]. Kockázati tényezőnek minősül az életkor, a betegségben eltöltött idő és a cukorbetegség típusa (a 2-es típusú diabetes mellitusban szenvedók körében gyakoribb), de életmódbeli tényezôkkel is találtak összefüggéseket (például dohányzás, túlsúly) $[6,7]$. A diabeteses neuropathia a leggyakoribb oka az alsó lábszár nem traumás amputációjának is [8].

E szövődmény megléte az évek elörehaladtával a betegek jelentős hányadánál fájdalmas tüneteket is produkál [9], ami a további életminőség-romlás mellett a költségek szempontjából is problémát okoz a szükséges fájdalomcsillapító szerek vagy éppen a munkából való kiesés és egyéb indirekt költségtényező́k miatt. A fájdalommal járó neuropathia diabetica során felmerülő kiadások akár 20\%-kal meghaladhatják a szövődmények nélküli betegek költségeit, ami öt év, betegségben (szövődménnyel) eltöltött idő után 31\%-ra emelkedhet egy tanulmány szerint [10].

Az egyes betegségek, betegségcsoportok epidemiológiai hátterének ismerete segíthet a megfelelő egészségpolitikai intézkedések meghozatalában, további, megelőzést vagy kezelést vizsgáló elemzések elvégzésében $[11,12]$. A Nemzeti Egészségbiztosítási Alapkezelő 
(NEAK) adatbázisából leválogatott adatokból egyes betegségek, betegségcsoportok betegségteher-elemzésére több példát is láthattunk az elmúlt években a hazai és a nemzetközi szakirodalomban $[13,14]$.

Elemzésünk célja volt az idegrendszeri szövődménynyel járó, 2-es típusú diabetes mellitus kórképek közül a diabeteses polyneuropathia (DPN) okozta epidemiológiai és egészségbiztosítási betegségtehernek a vizsgálata.

\section{Adatok és módszerek}

Kutatásunkban kvantitatív, leíró, keresztmetszeti jelleggel vizsgáltuk a DPN epidemiológiai helyzetét Magyarországon, valamint a betegség egészségbiztosítási kiadásainak összetételét.

Az elemzésben felhasznált adatok a NEAK finanszírozási adatbázisából származnak a 2018. finanszírozási évre vonatkozóan. Az idegrendszeri komplikációt a DPN-kórképpel, a Betegségek Nemzetközi Osztályozása (BNO, 10. revízió) szerinti G6320-as kóddal azonosítottuk.

Az elemzésbe 14 egészségbiztosítási ellátási formát vontunk be, ezek az alábbiak: háziorvosi ellátás, otthoni szakápolás, gondozás, járó-, aktív-, illetve krónikusfekvőbeteg-szakellátás, képalkotó (CT, MRI, PET) és laboratóriumi diagnosztika, gyógyszer-ártámogatás, tételes elszámolás alá eső egyszer használatos eszközök, implantátumok, gyógyszerek és nagy értékú mútéti eljárások, gyógyászatisegédeszköz-ártámogatás, valamint mentés és betegszállítás. (A mentés esetében a rendelkezésre álló adatok tekintetében csak a betegszámot elemeztük.) Az aktív- és krónikusfekvőbeteg-szakellátásra vonatko- zóan azokat az eseteket vizsgáltuk, amelyeknél a DPN ellátást indokló (az adatlap 26. mezője: a 3. ápolást indokló diagnózisok közül az 1 . helyen szereplő) diagnózisként került bejelentésre.

A vizsgálatba bevont betegségek terheinek elemzésekor meghatároztuk az éves egészségbiztosítási kiadásokat és a költségek megoszlását, korcsoportos és nemenkénti bontásban. A pénznemeket - USD, EUR - a Magyar Nemzeti Bank 2018. évi éves átlagárfolyamán számoltuk.

Az epidemiológiai jellemzés tekintetében vizsgáltuk továbbá az éves betegszámokat, valamint a 100000 lakosra jutó prevalenciát, korcsoportok és nemek szerint is vizsgálva. A prevalencia számításakor a járóbeteg-szakellátás igénybevételi adatait osztottuk az adott korcsoporthoz, illetve nemhez tartozó lakosságszámmal, 100000 före vetítve az értékeket. Az elemzés során a két nemet hét-hét korcsoportra bontva is vizsgáltuk $(<24 ; 25-34$; 35-44; 45-54; 55-64; 65-74; >75 év). A teljes populációra számított, valamint korcsoportos prevalencia kiszámításához a Központi Statisztikai Hivatalnak a lakónépességre vonatkozó 2018. évi adatait használtuk fel.

A magyar egészségügyi ellátórendszer felépítésének, szabályozásának és múködésének leírása máshol részletesen is ismertetésre került [15-23].

\section{Eredmények}

Az 1. táblázat mutatja a kórképhez tartozó betegszámokat a 2018-as évben. DPN-kórképpel a vizsgált évben 91550 fö kereste fel háziorvosát, 90365 fó jelent meg járóbeteg-szakrendelésen, illetve 88826 beteg ré-

1. táblázat |A diabeteses polyneuropathia betegszámai és egészségbiztosítási kiadásainak összege ellátási típusonként (NEAK, 2018)

\begin{tabular}{|c|c|c|c|c|c|c|}
\hline \multirow{2}{*}{$\begin{array}{l}\text { Ellátási forma } \\
\text { (NEAK-kassza) }\end{array}$} & \multicolumn{3}{|c|}{ Betegszám (fö) } & \multicolumn{3}{|c|}{ Kiadás $(\mathrm{Ft})$} \\
\hline & Férfi & Nó & Együtt & Férfi & Nó & Együtt \\
\hline Háziorvosi ellátás & 40437 & 51113 & 91550 & 187928798 & 239831043 & 427759842 \\
\hline Otthoni szakápolás & 29 & 45 & 74 & 2583821 & 3181445 & 5765266 \\
\hline Betegszállítás & 146 & 288 & 434 & 2521928 & 3644204 & 6166131 \\
\hline Mentés & 1 & 5 & 6 & - & - & - \\
\hline Járóbeteg-szakellátás & 40271 & 50094 & 90365 & 329288765 & 379287870 & 708576635 \\
\hline Gondozóintézeti gondozás & 67 & 90 & 157 & 1251503 & 1464779 & 2716282 \\
\hline Laboratóriumi ellátás & 11675 & 13317 & 24992 & 1704825 & 2136372 & 3841197 \\
\hline CT, MRI & 169 & 229 & 398 & 4092299 & 5790711 & 9883010 \\
\hline PET & 0 & 0 & 0 & 0 & 0 & 0 \\
\hline Aktívfekvőbeteg-szakellátás & 0 & 0 & 0 & 0 & 0 & 0 \\
\hline Krónikusfekvőbeteg-szakellátás & 1 & 0 & 1 & 780120 & 0 & 780120 \\
\hline Tételes elszámolás & 0 & 0 & 0 & 0 & 0 & 0 \\
\hline Gyógyszer-ártámogatás & 39175 & 49651 & 88826 & 2324366626 & 2864396329 & 5188762954 \\
\hline Gyógyászati segédeszközök ártámogatása & 2310 & 2314 & 4624 & 143557701 & 129692590 & 273250290 \\
\hline Összesen & - & - & - & 2998076508 & 3629425475 & 6627501983 \\
\hline
\end{tabular}

$\mathrm{CT}$ = komputertomográfia; MRI = mágnesesrezonancia-képalkotás; NEAK = Nemzeti Egészségbiztosítási Alapkezelő; PET = pozitronemissziós tomográfia 


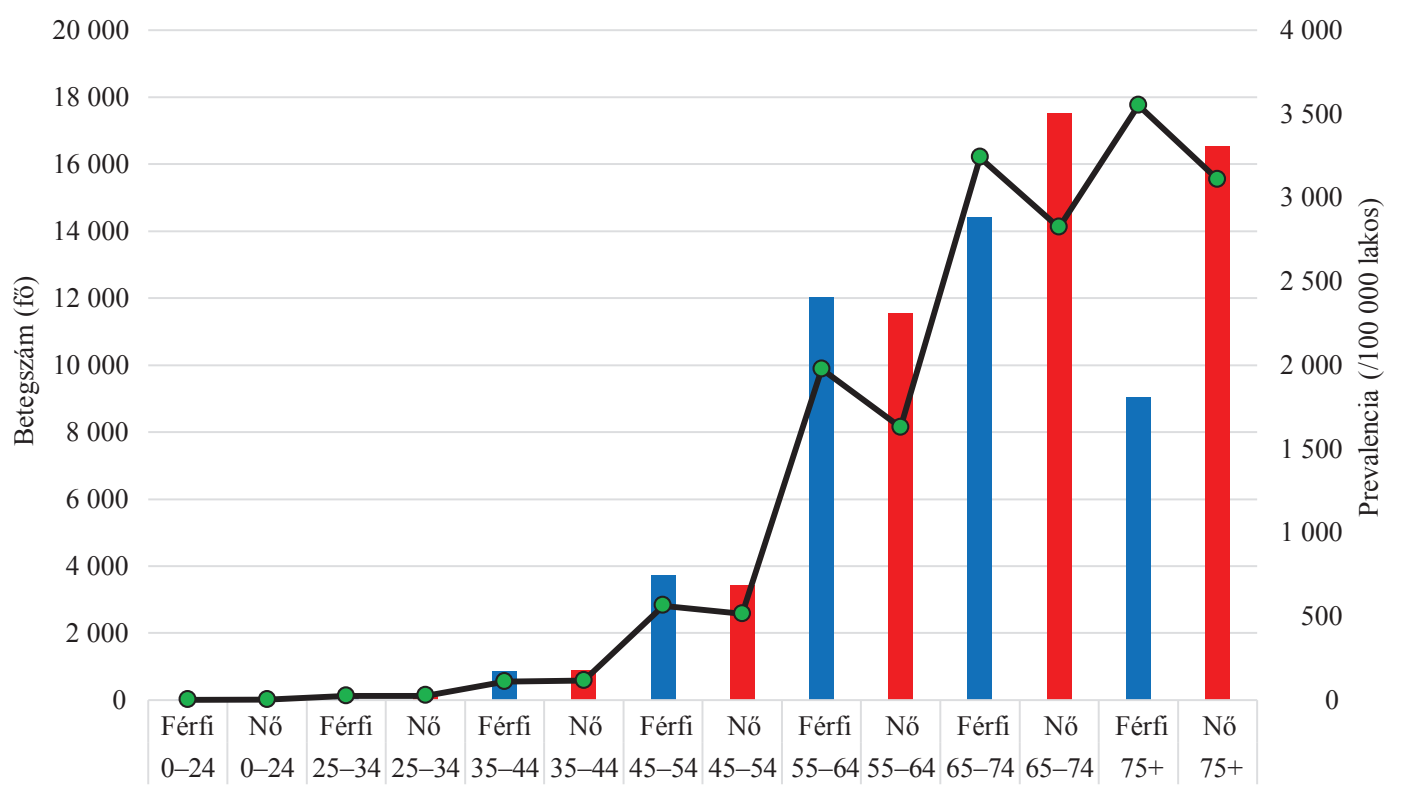

Korcsoportok (év)

1. ábra $\quad$ A 100000 lakosra jutó prevalencia diabeteses polyneuropathia tekintetében a járóbeteg-szakellátás adatai szerint, nemenkénti bontásban (NEAK, 2018)

NEAK = Nemzeti Egészségbiztosítási Alapkezelő

szesült gyógyszeres kezelésben a rendelkezésre álló adatok alapján. Az egyes ellátási szintek között átfedések előfordulhatnak (ugyanazon beteg megjelenhet egy éven belül háziorvosánál, járóbeteg-szakrendelésen és gyógyszer-ártámogatásban is részesülhet e kórképhez köthetően), ezért összbetegszámot nem adtunk meg. Az aktív- és krónikusfekvőbeteg-szakellátáson belül a vizsgált BNO-kód nem használatos mint fődiagnózis. A DPN-nel mint egyéb diagnózissal is mindössze 223 fó jelent meg az aktív- és 40 fó a krónikusfekvőbeteg-szakellátásban.

Meghatároztuk továbbá a 100000 lakosra jutó prevalenciát a járóbeteg-szakellátás igénybevételi adatai alapján, melyet az 1. ábra mutat. A vizsgált kórkép előfordulási gyakorisága a férfiak körében némileg alacsonyabb, mint a nőknél (1,13-szor magasabb a nők aránya). A teljes népességre számolt, 100000 főre vetített prevalencia $862 / 100000$ fó a férfiak, 981/100 000 fó a nők esetében, együtt 924/100 000 fó a járóbeteg-szakellátásban. Ugyancsak meghatároztuk a betegség korcsoportos prevalenciáját. A DPN előfordulási gyakorisága a 25 év alattiaknál 2,53/100 000 fö; kiemelendő, hogy e mutató a nők körében magasabb (nők: 2,97; férfiak:1,56). A vizsgált adatokból az látszik, hogy 55 év felett a prevalencia erősen emelkedni kezd. A vizsgált évben 100000 lakosra az 55-64 éveseknél 1789 beteg jutott, a 65-74 éveseknél 2996 beteg, a 75 év felettiek körében pedig már 3251 beteg, és a férfiak között szintén gyakoribb ez a betegség (nők: 3108/100 000 fó; férfiak: 3551/100 000 fö).
A betegek korcsoportos megoszlását tekintve elmondható, hogy a két, leggyakrabban igénybe vett ellátási forma - a háziorvosi ellátás és a járóbeteg-szakellátás - esetében is a 65-74 évesek jelentek meg a legnagyobb számban. A korcsoportok megoszlása mindkét esetben nagyjából azonos: a DPN-nel diagnosztizáltak 89,34\%-a 55 év feletti, 64,72\%-a 65 év feletti és 30,61\%-a 75 év feletti volt 2018-ban. Az abszolút betegszám tekintetében megfigyeltük, hogy a 45-64 éves korosztály kivételével minden esetben a nók betegszáma magasabb. Ugyanakkor ha a korcsoportos prevalenciát vizsgáljuk,
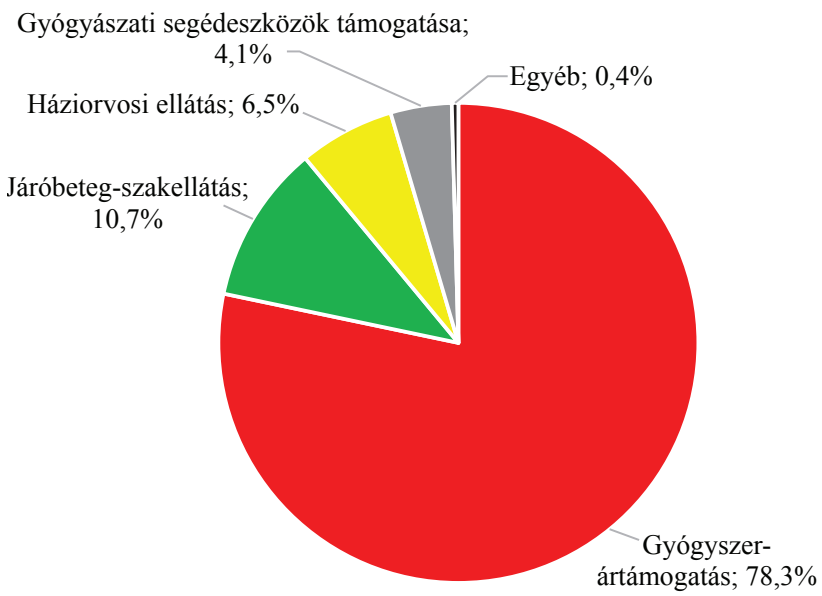

2. ábra A diabeteses polyneuropathia kezelésére fordított egészségbiztosítási kiadások megoszlása (NEAK, 2018)

NEAK = Nemzeti Egészségbiztosítási Alapkezelő 
45 év felett minden korcsoportban a férfiak esetében figyelhettünk meg magasabb előfordulási gyakoriságot.

A továbbiakban az egészségbiztosítási kiadásokat vizsgáltuk részletesebben. 2018-ban a DPN-ben szenvedő betegek kezelésére a NEAK 6,63 milliárd Ft (24,52 millió USD; 20,78 millió EUR) fordított a vizsgált ellátási típusokban (1. táblázat). Az összkiadás legnagyobb hányadát a gyógyszer-ártámogatás finanszírozása tette ki $(78,29 \%)$, ezt követték a járóbeteg-szakellátás (10,69\%) és a háziorvosi ellátás $(6,45 \%)$ kiadásai. A többi ellátási forma a kiadásoknak összesen csupán a 4,56\%-át adta a DPN esetében (2. ábra). A kórkép ápolást indokló fódiagnózisként való jelentésének hiányában költségek sem merültek fel a fekvőbeteg-szakellátásban, azonban kísérő betegségként megjelölve további 37,30 millió Ft kiadás köthető hozzá. A nemek között nem tapasztaltunk jelentős eltérést a kiadások megoszlásában, az egyes szolgáltatásokon belül azonban a nókre fordított költségek aránya néhol magasabb - ugyanakkor a polyneuropathiás betegek 10\%-ánál nagyobb különbséget egyik ellátási típus-

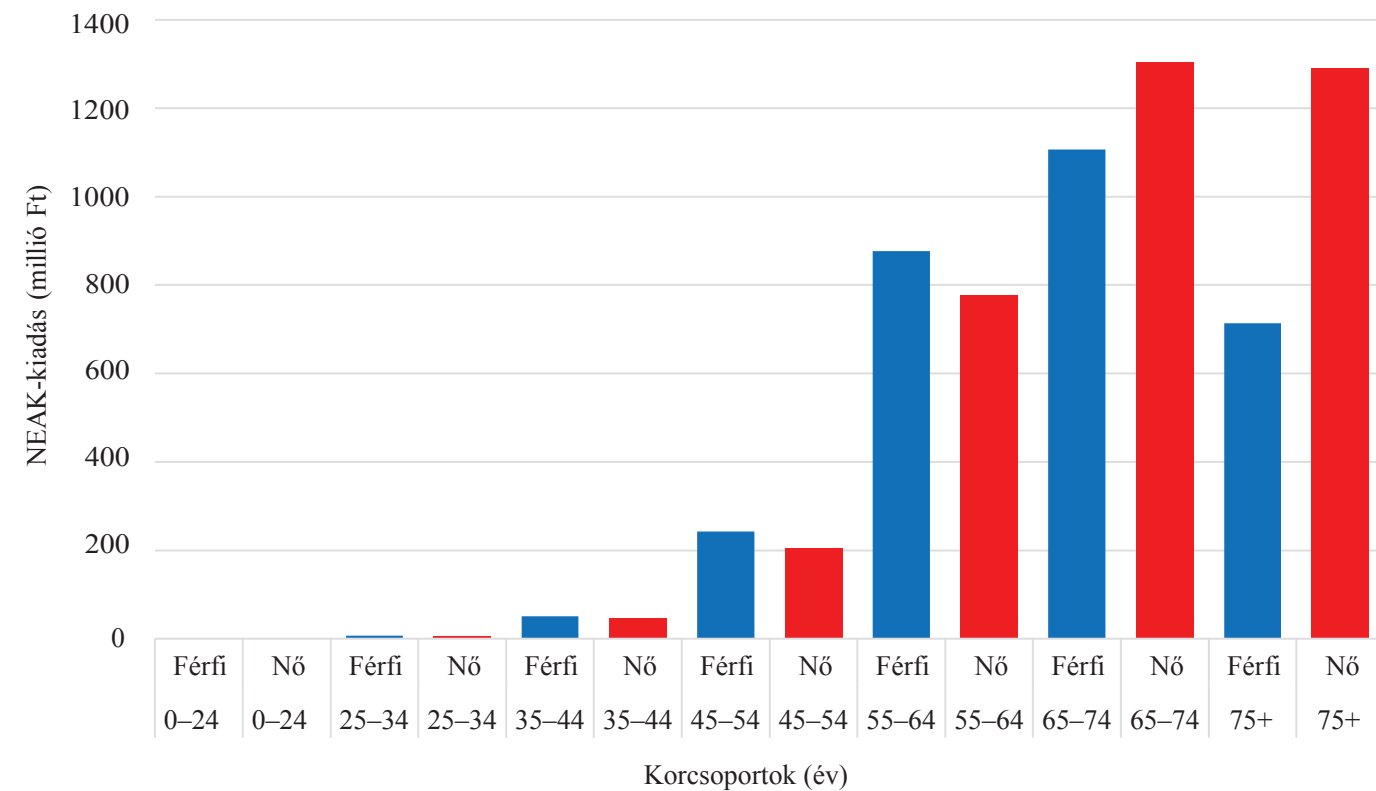

3. ábra A diabeteses polyneuropathia egészségbiztosítási kiadásának megoszlása korcsoportok és nemek szerint (NEAK, 2018) NEAK = Nemzeti Egészségbiztosítási Alapkezelő

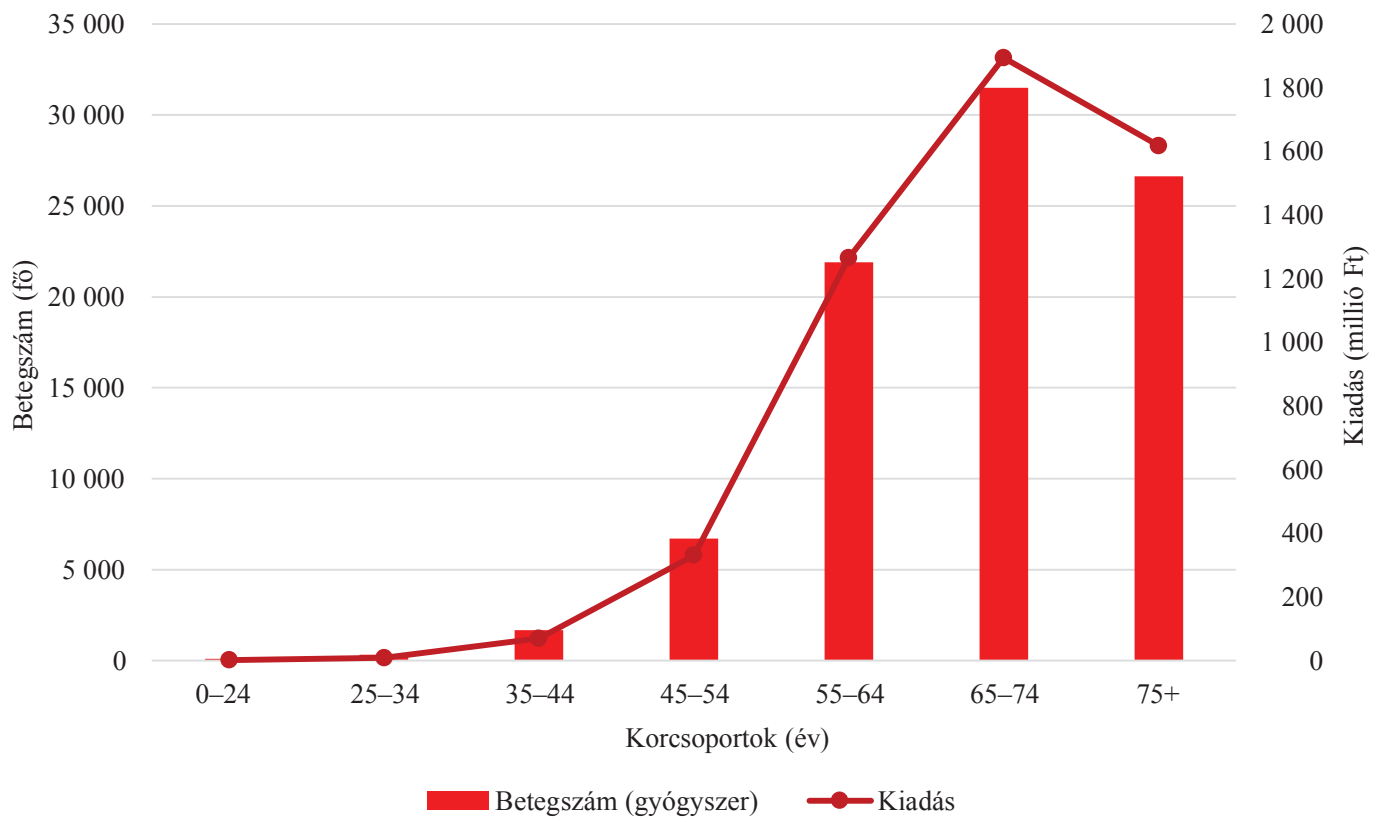

\begin{tabular}{l|l} 
4. ábra & $\begin{array}{l}\text { A diabeteses polyneuropathia korcsoportos egészségbiztosítási kiadásai és betegszámai a gyógyszer-ártámogatás adatait alapul véve (NEAK, 2018) } \\
\text { NEAK = Nemzeti Egészségbiztosítási Alapkezelő }\end{array}$
\end{tabular} 
nál sem találtunk a férfiak és a nők kezelésére fordított költségek között.

$\mathrm{Az}$ egészségbiztosítási kiadások az életkor tekintetében erős koncentrációt mutatnak, tehát a kiadások legnagyobb részét az idősebb betegpopuláció ellátására fordítják. Ez a koncentráció a nők esetében még erősebb. Korcsoportos bontásban láthatjuk, hogy az idősebb korosztályokban a nemek közti különbségek differenciáltabbak, a 75 év feletti nők kiadásai csaknem a kétszeresét teszik ki a férfiakéinak. Az 55-64 éves korosztályig a férfiak kiadásai magasabbak, mint a nőkéi, az idősebb korcsoportokban azonban megfordul a tendencia, és a nók kiadásai érik el a magasabb értéket (3. ábra).

A diabetes neurológiai jellegű szövődményeinél a legnagyobb kiadási tételt a kezeléshez és a fájdalomcsillapításhoz szükséges gyógyszerek ártámogatása jelenti. A meghatározó gyógyszerkiadások tekintetében tehát a betegszám és az egészségbiztosítási kiadások korcsoportos bontásban szinkrónban jelennek meg. Az ártámogatás mintegy $92 \%$-a az 55 év feletti betegkör kezelésére fordul, és a gyógyszeres kezelésben részesülők csaknem harmada $(31,18 \%) 75$ év feletti (4. ábra).

$\mathrm{Az}$ egy betegre jutó éves átlagos NEAK-kiadás a DPN legnagyobb betegszámú ellátási típusa; 2018-ban a háziorvosi ellátás vonatkozásában 74142 Ft (274 USD; 233 EUR) volt a férfiaknál, $71008 \mathrm{Ft}$ (263 USD; 223 EUR) a nőknél, átlagosan 72392 Ft (268 USD; 227 EUR).

\section{Megbeszélés}

Elemzésünk célja a DPN egészségbiztosítási betegségterhének felmérése volt. Megállapítottuk, hogy 2018ban a DPN-ben szenvedő betegek kezelésére a NEAK 6,63 milliárd Ft-ot fordított, a teljes népességre számolt, 100000 före vetített prevalencia pedig 862/100 000 fó volt a férfiak és 981/100 000 fö a nók esetében.

A Global Burden of Disease Study (GBD) Magyarországra vonatkozó adatai alapján Magyarországon 2000ben a diabetes (szövődmény meglététól vagy típusától függetlenül) a 14. leggyakoribb halálokként szerepelt, ez 2017-re a 11. helyre került. Az egészségkárosodással korrigált életévek (DALY) számát illetôen azonban a diabetes már 2000-ben a 9., 2017-ben pedig a 7. helyen szerepelt [24]. A magyar és - egy kivétellel - a WHOadatok is emelkedő tendenciát mutatnak, hazánkban azonban mindig a WHO Európai Régiójának átlaga feletti számokat láthatunk, és a növekedés mértéke is nagyobb [25-27].

Nemzetközi szakirodalmi közlemények is alátámasztják, hogy a diabetes szövődményei közül a neuropathia megelőzése kiemelten fontos a betegség progressziója során kialakuló, gyakran erős fájdalomérzet miatt, mely mindemellett a beteg és a biztosító számára egyaránt jelentős többletköltséget generál. A diabeteses láb pedig a cukorbetegséghez köthető egyik legsúlyosabb, komplex kezelést igénylő kórkép [28-30], melynek kialakulásához a neuropathia jelenléte bizonyítottan nagyban hoz- zájárul, és az esetek mintegy háromnegyedében jelenik meg oki tényezőként [31, 32]. Incidenciájának és prevalenciájának pontos megállapítása azonban nehéz feladat, a kór multifaktoriális eredete és specifikus BNO-kód hiánya miatt (jóllehet a BNO 11. revíziója már tartalmaz kódot a diabeteses láb fekélyére, valamint a Charcot-lábra vonatkozóan).

Számos bizonyíték mutat rá, hogy ez a betegség, illetve a vele járó egyéb szövődmények kockázata életmódváltással csökkenthetó, idetartozik a fizikai aktivitás növelése, a dohányzás abbahagyása és minőségi diéta tartása. Fontos, hogy ezek a rizikófaktorok bizonyítottan nemcsak a neuropathiás, hanem a más típusú szövődmények kialakulásában - így megelőzésében - is szerepet játszanak [33]. Egészségpolitikai szempontból is kiemelt jelentőséggel bír az egészségtudatosság növelése a lakosság körében és ezzel az elkerülhető megbetegedések és halálozások számának csökkentése. Ezt az életmódhoz kötött termékek megadóztatása [34], egészségnevelő, preventív jellegú programok és szû́rőprogramok szervezése is segítheti [31]. Nem utolsósorban pedig a diabetesnek és komplikációinak diagnosztizálása és kezelése kapcsán a szakmai irányelv folyamatos aktualizálása és betartása is kritikus fontosságú. Magyarországon jelenleg a diabeteses láb ellátásáról található hatályos irányelv [35]; a cukorbetegek kezeléséról és gondozásáról szóló dokumentum aktualizálása megtörtént 2020-ban [36].

Nemzetközi szinten a cukorbetegség egyes szövődményeinek incidenciája és prevalenciája nagy szórást mutat. Általánosságban azonban elmondható, hogy a kutatások zömében a neuropathiás szövődmények jelenlétét a diabeteses populációhoz viszonyítva közlik, ezért az ily módon meghatározott magyarországi mutatószámok további kutatások alapját képezik a jövőben.

Elemzésünk újdonsága és bizonyos értelemben limitációja ugyanaz: való életbeli adatokat használtunk a DPN betegségterhének meghatározásához. A humán klinikai vizsgálatokból származó adatok általában pontosabbak, mint a finanszírozási adatok, hátrányuk azonban, hogy viszonylag kis létszámú beteg bevonásával folynak. A nagy, országos kiterjedésû, való életbeli, rutinszerúen gyújtött adatokon alapuló elemzések előnye, hogy teljes országos populációt fednek le, hátrányuk, hogy bizonyos kódolási torzítások lehetnek ezen adatbázisokban [37, 38]. A magyarországi kódolási gyakorlat miatt előfordulhatnak a vizsgált betegpopulációban l-es típusú diabetes mellitusban, polycystás ovarium szindrómában és gestatiós diabetes mellitusban szenvedő betegek is. Kiemelendő továbbá, hogy az El140-es kóddal is azonosíthatók idegrendszeri szövődménnyel, ezen belül polyneuropathiával kezelt betegek, amit eredményeinken keresztül az aktívfekvőbeteg-szakellátás „teljes hiánya” mutat. Az osztályos betegek esetében a kedvezőbb elszámolás és egyes, csak szakorvosi javaslatra felírható gyógyszerek miatt az ellátást indokló diagnózist más BNO-kóddal is bejelenthetik. Ugyanakkor elöfordulhat az is, hogy - szintén a fent megnevezett okokból fakadóan - nem 
diabeteses, hanem egyéb eredetû́ idegrendszeri problémával küszködő betegeket (például stroke) is ezzel a kóddal dokumentálnak, ami megnehezíti a vizsgált betegpopuláció pontos beazonosítását.

Az aktívfekvőbeteg-szakellátás mellett a krónikusfekvőbeteg-szakellátásban (benne a rehabilitációs ellátásokban) sem jelennek meg ezek a betegek önálló fódiagnózissal. Megfontolásra érdemes a rehabilitációs ellátások átgondolása $[39,40]$.

\section{Következtetés}

Összességében elmondhatjuk, hogy az egészségbiztosítási kiadások mérséklése és a lakosság életminőségének javítása céljából a kezelés mellett a megelőzésre is kiemelt figyelmet kell fordítani. Az egészségtelen életmódból adódó megbetegedések elkerülése hosszú távon kapacitást, forrást szabadít fel az egészségügy számára, mely végső soron az allokatív hatékonyság javítása érdekében elengedhetetlen az ágazaton belül.

Anyagi támogatás: A kézirat az „EFOP-3.6.2-16-201700009: Klinikai kutatások tematikus hálózatának kialakítása és nemzetköziesítése” projekt keretében az „Egészségbiztosítási és klinikai real-world adatvagyon hasznosítása" alprojekt támogatásával készült.

Szerzôi munkamegosztás: A vizsgálat tervezése: B. I., Cs. T. Adatok gyújtése és elemzése: Cs. T., B. I. Az adatgyüjtés és -elemzés ellenőrzése: E. D., N. N., K. Zs. Statisztikai elemzések: B. I., Cs. T., E. D., N. N. Az eredmények értelmezése: Cs. T., B. I., K. Zs., W. I., J. J. Irodalomkutatás: Cs. T., W. I., J. J., B. I. A kézirat szövegezése: Cs. T., E. D., N. N., K. Zs., W. I., J. J., B. I. A cikk végleges változatát valamennyi szerző elolvasta és jóváhagyta.

Érdekeltségek: A szerző́knek nincsenek érdekeltségeik.

\section{Köszönetnyilvánítás}

A szerzők köszönetet mondanak az „EFOP-3.6.2-16-2017-00009: Klinikai kutatások tematikus hálózatának kialakítása és nemzetköziesítése" projekt keretében nyújtott támogatásért (szakmai vezető: prof. dr. Kovács L. Gábor, a Magyar Tudományos Akadémia rendes tagja).

\section{Irodalom}

[1] Saeedi P, Petersohn I, Salpea P, et al. Global and regional diabetes prevalence estimates for 2019 and projections for 2030 and 2045: results from the International Diabetes Federation Diabetes Atlas, 9th edition. Diabetes Res Clin Pract. 2019; 157: 107843

[2] Jermendy Gy, Kempler P, Abonyi-Tóth Zs, et al. Changes in features of diabetes care in Hungary in the period of years 20012014. Aims and methods of the database analysis of the National Health Insurance Fund. [A cukorbeteg-ellátás mutatóinak alakulása Magyarországon 2001-2014 között. Az Országos Egészség- biztosítási Pénztár adatbázis-elemzésének célja és módszertana.] Orv Hetil. 2016; 157: 1259-1265. [Hungarian]

[3] Jermendy Gy, Kiss Z, Rokszin Gy, et al. Decreasing incidence of pharmacologically treated type 2 diabetes in Hungary from 2001 to 2016: a nationwide cohort study. Diabetes Res Clin Pract. 2019; 155: 107788 .

[4] Alleman CJ, Westerhout KY, Hensen M, et al. Humanistic and economic burden of painful diabetic peripheral neuropathy in Europe: a review of the literature. Diabetes Res Clin Pract. 2015; 109: 215-225.

[5] Kempler P, Keresztes K, Kerényi Zs, et al. Prevalence of neuropathy in diabetes mellitus. In: Kempler P, Várkonyi T. (eds.) Neuropathies in clinical practice. [A neuropathia prevalenciája diabetes mellitusban. In: Kempler P, Várkonyi T. (szerk.) Neuropathiák a klinikai gyakorlatban.] Zafir Press, Budapest, 2012; pp. 199-222. [Hungarian]

[6] Papanas N, Ziegler D. Risk factors and comorbidities in diabetic neuropathy: an update 2015. Rev Diabet Stud. 2015; 12: 48-62.

[7] Clair C, Cohen MJ, Eichler F, et al. The effect of cigarette smoking on diabetic peripheral neuropathy: a systematic review and meta-analysis. J Gen Intern Med. 2015; 30: 1193-1203.

[8] Abola MT, Bhatt DL, Duval S, et al. Fate of individuals with ischemic amputations in the REACH Registry: three-year cardiovascular and limb-related outcomes. Atherosclerosis 2012; 221: $527-535$.

[9] Veves A, Backonja M, Malik RA. Painful diabetic neuropathy: epidemiology, natural history, early diagnosis, and treatment options. Pain Med. 2008; 9: 660-674.

[10] Kiyani M, Yang Z, Charalambous LT, et al. Painful diabetic peripheral neuropathy - health care costs and complications from 2010 to 2015. Neurol Clin Pract. 2020; 10: 47-57.

[11] Wittmann I, Kiss Z, Rokszin G, et al. Risk factors of dialysis and mortality in type 1 and 2 diabetes. A nationwide study. [A dialízis és a mortalitás kockázata 1 -es és 2 -es típusú cukorbetegségben. Széleskörû hazai felmérés.] Diabetol Hung. 2019; 27(Suppl 1): 67-68. [Hungarian]

[12] Christensen DH, Knudsen ST, Nicolaisen SK, et al. Can diabetic polyneuropathy and foot ulcers in patients with type 2 diabetes be accurately identified based on ICD-10 hospital diagnoses and drug prescriptions? Clin Epidemiol. 2019; 11: 311-321.

[13] Boncz I, Pónusz R, Elmer D, et al. Annual health insurance treatment cost of diabetic polyneuropathy based on routinely collected financing data. Value Health 2020; 23(Suppl 1): S1 17.

[14] Boncz I, Pónusz R, Elmer D, et al. Epidemiological disease burden of diabetic polyneuropathy based on routinely collected health insurance claims data. Value Health 2020; 23(Suppl 1): S121.

[15] Boncz I, Evetovits T, Dózsa Cs, et al. The Hungarian Care Managing Organization Pilot Program. Value Health Reg Issues $2015 ; 7: 27-33$.

[16] Varga V, Boncz I, Sebestyén A, et al. Utilization indicators of balneotherapy in Hungary. [A gyógyfürdőellátások igénybevételi mutatói Magyarországon.] Orv Hetil. 2019; 160(Suppl 1): 2228. [Hungarian]

[17] Boncz I, Vajda R, Ágoston I, et al. Changes in the health status of the population of Central and Eastern European countries between 1990 and 2010. Eur J Health Econ. 2014; 15(Suppl 1): 137-141.

[18] Endrei D, Molics B, Ágoston I. Multicriteria decision analysis in the reimbursement of new medical technologies: real-world experiences from Hungary. Value Health 2014; 17: 487-489.

[19] Boncz I, Sebestyén A. Financial deficits in the health services of the UK and Hungary. Lancet 2006; 368: 917-918.

[20] Eisingerné Balassa B, Csákvári T, Ágoston I. Health insurance pharmaceutical expenditures in Hungary. [Az egészségbiztositási gyógyszerkiadások alakulása Magyarországon.] Orv Hetil. 2019; 160(Suppl 1): 49-54. [Hungarian] 
[21] Boncz I, Kaló Z, Mohamed Ibrahim MI, et al. Further steps in the development of pharmacoeconomics, outcomes research, and health technology assessment in Central and Eastern Europe, Western Asia, and Africa. Value Health Reg Issues 2013; 2: 169170.

[22] Hornyák L, Nagy Z, Ilku L, et al. Price competition and reimbursement of biosimilar granulocyte-colony stimulating factor in Hungary. Expert Rev Pharmacoecon Outcomes Res. 2019; 19: 725-731.

[23] Boncz I, Nagy J, Sebestyén A, et al. Financing of health care services in Hungary. Eur J Health Econ. 2004; 5: 252-258.

[24] GBD 2017 Causes of Death Collaborators. Global, regional, and national age-sex-specific mortality for 282 causes of death in 195 countries and territories, 1980-2017: a systematic analysis for the Global Burden of Disease Study 2017. Lancet 2018; 392: 1736-1788. [Erratum: Lancet 2019; 393: e44.] [Erratum: Lancet 2018; 392: 2170.]

[25] Global Health Estimates 2016: Disease burden by cause, age, sex, by country and by region, 2000-2016. World Health Organization, Geneva, 2018.

[26] GBD 2017 Disease and Injury Incidence and Prevalence Collaborators. Global, regional, and national incidence, prevalence, and years lived with disability for 354 diseases and injuries for 195 countries and territories, 1990-2017: a systematic analysis for the Global Burden of Disease Study 2017. Lancet 2018; 392: 1789-1858.

[27] Khan MA, Hashim MJ, King JK, et al. Epidemiology of type 2 diabetes - Global Burden of Disease and forecasted trends. J Epidemiol Glob Health 2020; 10: 107-111.

[28] Szabad G. Diabetic foot syndrome. [A diabeteses láb.] Orv Hetil. 2011; 152: 1171-1177. [Hungarian]

[29] Kolossváry E, Járai Z, Farkas K. Peripheral arterial disease and diabetes related lower limb amputations. Presentation of the epidemiological data and the analysis of potentialities in preventive strategy. [A perifériás verőérbetegséggel és a cukorbetegséggel összefüggő alsó végtagi amputációk. Epidemiológiai adatok bemutatása és a megelőző stratégia lehetőségeinek elemzése.] Orv Hetil. 2016; 157: 1266-1274. [Hungarian]

[30] Kolossváry E, Bánsághi Z, Szabó GV, et al. Ischemic origin of diabetic foot disease. Epidemiology, difficulties of diagnosis, options for prevention and revascularization. [A diabeteses láb ischaemiás eredete. Epidemiológia, a diagnózis nehézségei, prevenciós és revascularisatiós lehetőségek.] Orv Hetil. 2017; 158: 203-211. [Hungarian]

[31] Jermendy Gy. The diabetic foot syndrome: pathomechanism, clinical picture, current treatment and prevention. [Diabeteses láb szindróma: patomechanizmus, klinikai kép, korszerú terápia, megelőzés.] Lege Artis Med. 2012; 22: 249-256. [Hungarian]

[32] Tomlinson DR, Gardiner NJ. Diabetic neuropathies: components of etiology. J Peripher Nerv Syst. 2008; 13: 112-121.

[33] Kempler P, Tesfaye S, Chaturvedi N, et al. Autonomic neuropathy is associated with increased cardiovascular risk factors: the EURODIAB IDDM Complications Study. Diabet Med. 2002; 19: 900-909.

[34] Csákvári T, Németh N, Kerner Á, et al. Assessing the effect of the public health product tax in Hungary between 2011-2017. Value Health 2018; 21(Suppl 2): S52.

[35] Jermendy Gy, Hidvégi T, Pécsvárady Z. Healthcare professional guideline - Treatment of adult diabetic foot syndrome patients (pathology, diagnostics, therapy, prevention). [Egészségügyi szakmai irányelv - A diabeteses láb szindrómában szenvedő $\mathrm{cu}-$ korbetegek ellátása felnőttkorban (klinikai kép, diagnosztika, terápia, megelőzés).] Diabetol Hung. 2018; 26: 79-116. [Hungarian]

[36] Clinical guideline of the Ministry of Human Capacities about diagnosis, antihyperglycaemic treatment and care of adult diabetic patients. [Az Emberi Erőforrások Minisztériuma egészségügyi szakmai irányelve a diabetes mellitus kórismézéséről, a cukorbetegek antihyperglykaemiás kezeléséről és gondozásáról felnőttkorban.] Egészségügyi Közlöny 2020; LXX(12): 17591856. [Hungarian]

[37] Molics B, Boncz I, Leidecker E, et al. Health insurance aspects of physiotherapeutic care of neurology disorders in outpatient care. [A neurológiai kórképek fizioterápiás ellátásának egészségbiztosítási vonatkozásai a járóbeteg-szakellátásban.] Ideggyógy Szle. 2015; 68: 399-408.

[38] Endrei D, Zemplényi A, Molics B, et al. The effect of performance-volume limit on the DRG based acute care hospital financing in Hungary. Health Policy 2014; 115: 152-156.

[39] Péter I, Jagicza A, Ajtay Z, et al. Balneotherapy in psoriasis rehabilitation. In Vivo 2017; 31: 1163-1168.

[40] Molics B, Hanzel A, Nyárády J, et al. Utilization indicators of physiotherapy in musculoskeletal and connective tissue disorders for outpatient care. [Fizioterápiás járóbeteg-ellátás igénybevételi mutatói a mozgásszervi kórképek kezelésében.] Magy Traumatol Ortop Kézseb Plaszt Seb. 2013; 56: 305-315. [Hungarian]

(Csákvári Tímea, Zalaegerszeg, Landorhegyi u. 33., 8900 e-mail: timea.csakvari@etk.pte.hu)

A cikk a Creative Commons Attribution 4.0 International License (https://creativecommons.org/licenses/by/4.0/) feltételei szerint publikált Open Access közlemény, melynek szellemében a cikk bármilyen médiumban szabadon felhasználható, megosztható és újraközölhető, feltéve, hogy az eredeti szerző és a közlés helye, illetve a CC License linkje és az esetlegesen végrehajtott módosítások feltüntetésre kerülnek. (SID_1) 